\title{
FOODBORNE INFECTIONS AND INTOXICATIONS IN POLAND IN 2016*
}

\author{
ZATRUCIA I ZAKAŻENIA POKARMOWE W POLSCE W 2016 ROKU*
}

\author{
National Institute of Public Health - National Institute of Hygiene (NIPH-NIH) in Warsaw, \\ Department of Epidemiology of Infectious Diseases and Surveillance \\ Zakład Epidemiologii Chorób Zakaźnych i Nadzoru Narodowego Instytutu Zdrowia Publicznego \\ - Państwowego Zakładu Higieny w Warszawie
}

\begin{abstract}
AIM. The purpose of this study is to assess the epidemiological situation of food poisonings and infections in Poland in 2016.

MATERIALS AND METHODS. The evaluation was based on the analysis of information sent to Department of Epidemiology NIPH-NIH through ROE (Pol. Rejestr Ognisk Epidemicznych)- (an electronic system created for uploading, transfer and analysis of data acquired during the outbreak investigations). Additional sources for the analysis were NIPH-NIH annual bulletins (Czarkowski MP et al. "Infectious diseases and poisonings in Poland", 2010-2016. Warsaw, NIPH-NIH and GIS).

RESULTS. In 2016 a total number of 680 foodborne infections and intoxications outbreaks were reported in which 22908 persons were exposed and 7186 (out of which 38\% were children up to 14 years of age) got sick. Hospitalization was required for 1603 of patients. The most frequent etiological agent was Salmonella sp. $-37,6 \%, 3$ and $28,4 \%$ of cases). Viruses were responsible for $22,5 \%$ of outbreaks and $28,6 \%$ of cases (And among them rotaviruses- $10,8 \%$ of outbreaks and 5,2\% of cases and noroviruses- $11,1 \%$ of outbreaks and $23,3 \%$ of cases). In $27,5 \%$ of outbreaks no etiological agent was found. Just as in 2015 private household was the most frequent place of an outbreak- 323 outbreaks (47,5\%), and after that- hospital- 135 outbreaks (19,9\%). In 2016 in more than $81 \%$ of outbreaks no vehicle was found and in remaining the most frequent vehicle were eggs and egg products) ( $25 \%$ of outbreaks of known vehicle).

CONCLUSIONS. The increase in the both percentage of reported salmonellosis cases among the group of bacterial foodborne infections and the increase of foodborne outbreaks of Salmonella Enteritidis etiology along with the fact of the occurrence of large, multistate outbreak of this etiology with Polish eggs as a vehicle indicates an alarming situation and the necessity of microbiological surveillance enchantment in relation to abovementioned products. Moreover an increase in the percentage of unknown etiology outbreaks, in which clinical symptoms of cases suggest viral etiology indicates the need for more frequent testing oriented for those pathogens during epidemiological investigations.
\end{abstract}

Key words: food poisonings and infections, foodborne outbreaks, epidemiology, Poland, 2016

\section{STRESZCZENIE}

CEL. Celem pracy jest ocena sytuacji epidemiologicznej zatruć i zakażeń pokarmowych w Polsce w roku 2016. MATERIALY I METODY. Ocenę przeprowadzono na podstawie wyników analizy danych przesyłanych do Zakładu Epidemiologii Chorób Zakaźnych i Nadzoru NIZP-PZH za pośrednictwem elektronicznego systemu Rejestr Ognisk Epidemicznych - ROE, służącego do gromadzenia i analizy danych z dochodzeń epidemiologicznych w ogniskach zatruć i zakażeń pokarmowych prowadzonych przez stacje sanitarno-epidemiologiczne. Źródłem informacji były także dane z biuletynów rocznych „Choroby zakaźne i zatrucia w Polsce” - 2010-2016 (Czarkowski MP i in. Warszawa, NIZP-PZH i GIS)

\footnotetext{
*Article was written under the task No.7/EM.1/2018/ Praca została wykonana w ramach zadania nr 7/EM.1/2018

(C) National Institute of Public Health - National Institute of Hygiene / Narodowy Instytut Zdrowia Publicznego - Państwowy Zakład Higieny
} 
WYNIKI. W 2016 r. zarejestrowano 680 ognisk zatruć/zakażeń przenoszonych drogą pokarmową, w których narażonych było 22908 osób, a zachorowało 7 186, z czego ponad 38\% to dzieci do 14 roku życia. Ogółem hospitalizacji wymagały 1603 osoby. Dominującym czynnikiem etiologicznym w ogniskach były pałeczki z rodzaju Salmonella - 37,6\% ognisk i 28,4\% zachorowań. Wirusy były czynnikiem etiologicznym w 22,5\% ognisk i 28,6\% zachorowań (a wśród nich rotawirusy w 10,8\% ogółu ognisk i 5,2\% ogółu zachorowań oraz norowirusy w 11,1\% ogółu ognisk i 23,3\% ogółu zachorowań). W 27,5 \% ognisk nie ustalono czynnika etiologicznego. Podobnie jak w roku 2015 najczęstszym miejscem wystąpienia ogniska było gospodarstwo domowe - 323 ogniska (47,5\%), a następnie szpital - 135 ognisk (19,9\%). W prawie $81 \%$ nie ustalono nośnika zakażenia. W 25\% ognisk, w których ustalono nośnik zakażenia najczęściej były to jaja i potrawy z jaj.

WNIOSKI. Wzrastająca liczba ognisk o etiologii Salmonella Enteritidis oraz liczba osób chorujących w tych ogniskach wskazuje na niepokojącą sytuację i konieczność zaostrzenia nadzoru zarówno przez służby sanitarne, jak i weterynaryjne. Wzrastający odsetek ognisk o nieustalonej etiologii, w których objawy są charakterystyczne dla ognisk o etiologii wirusowej, wskazuje na potrzebę częstszego wykonywania badań laboratoryjnych w ogniskach w kierunku tych czynników.

Słowa kluczowe: zatrucia i zakażenia pokarmowe, ogniska zatruć i zakażeń pokarmowych, epidemiologia, Polska, rok 2016

\section{INTRODUCTION}

The registry of foodborne outbreaks is carried out in Poland at the National Institute of Public Health - NIH since 1988. Annual assessment of the epidemiology of foodborne diseases in Poland is based on the data collected within this registry, as well as data from foodborne outbreaks investigations. It is designed to track changes in the number of outbreaks, involvement of various etiological factors and the characteristics of other specific features of outbreaks. For the purpose of surveillance the outbreak is defined as the occurrence, under specific conditions, of two or more cases caused by the same etiological factor, with at least one of the cases presenting with symptoms.

\section{MATERIAL AND METHODS}

The assessment of the epidemiological situation of outbreaks of foodborne disease in Poland in 2016, was based on analysis of data sent by local and voivodeship sanitary stations through ROE (Pol. Rejestr Ognisk Epidemicznych) as well as from the annual bulletins (Czarkowski MP et al. "Infectious diseases and poisonings in Poland" - 2010-2016) (1). ROE is an electronical system created for uploading, transferring and analysis of the data acquired during the outbreak investigations.

\section{RESULTS}

Numbers of cases and the incidence of registered food poisonings and infections in Poland in the years 2010-2016 with regard to their etiology are summarized in Table I. In 2016, among food poisonings and infections caused by bacterial factors, an increase was observed $(12 \%)$. It derived from even bigger increase (over 18\%) in Salmonella infections with the number

\section{WSTĘP}

Rejestr ognisk zatruć i zakażeń wywołanych patogenami przenoszonymi drogą pokarmową prowadzony jest w Polsce w Narodowym Instytucie Zdrowia Publicznego - PZH od 1988 roku. Na podstawie analizy danych gromadzonych $\mathrm{w}$ ramach rejestru co roku przeprowadzana jest ocena sytuacji epidemiologicznej chorób przenoszonych drogą pokarmową. Ocena ta ma na celu śledzenie zmian zachodzących w liczbie ognisk, udziale poszczególnych czynników etiologicznych, wskazanie najczęstszych nośników i źródeł zakażeń oraz innych cech charakteryzujących ogniska. W krajowym nadzorze epidemiologicznym w przypadku chorób przenoszonych drogą pokarmową ognisko definiowane jest jako wystąpienie, w określonych warunkach, zachorowania i/lub zakażenia dwóch lub więcej osób spowodowanych tym samym czynnikiem etiologicznym, przy czym przynajmniej u jednej z osób muszą wystąpić objawy chorobowe.

\section{MATERIAŁ I METODY}

Ocenę sytuacji epidemiologicznej występowania ognisk zatruć i zakażeń pokarmowych w Polsce w 2016 r. przeprowadzono na podstawie wyników analizy danych przesyłanych przez powiatowe i wojewódzkie stacje sanitarno-epidemiologiczne za pośrednictwem systemu Rejestru Ognisk Epidemicznych (ROE), jak również analizy danych z biuletynów rocznych (Czarkowski MP i in. „Choroby zakaźne i zatrucia w Polsce" - 2010-2016) (1). System ROE jest elektronicznym narzędziem służącym do wprowadzania, przekazywania i analizy danych zebranych w trakcie dochodzeń epidemiologicznych w ogniskach zatruć i zakażeń pokarmowych. 
of cases bigger than the median from years 2010-2014 by $8,6 \%$. Also an increase in registered Listeria cases was registered, which was bigger the median from the years 2010-2014.

In 2016 in a group called "bacterial food poisoning" (caused by zoonotic Salmonella types A02.0, staphylococci - A05.0, Clostridium botulinum A05.1, C. perfringens - A05.2, other specified bacteria, Vibrio parahaemolyticus in this and Bacillus cereus - A05.3-A05.8, and the factors unspecified - A05.9) a total number of 10734 cases was recorded (incidence 27,9 per 100 000). In this group an increase was observed, both in incidence as well as the number of cases, and it was bigger than the median for 2010-2014. The highest incidence was observed in Pomorskie, Lubelskie and Swietokrzyskie voivodeship and it was 37,5; 37,4; and 35 per 100000 accordingly (Tab. IIA).

\section{WYNIKI}

Liczby zachorowań i wskaźniki zapadalności zarejestrowanych zatruć i zakażeń pokarmowych w Polsce w latach 2010 - $2016 \mathrm{z}$ informacją o ich czynniku etiologicznym przedstawiono w tabeli I. W 2016 r. wśród zatruć i zakażeń pokarmowych spowodowanych czynnikami bakteryjnymi zarejestrowano wzrost liczby przypadków o $12 \%$. Wynikał on głównie ze wzrostu liczby przypadków zakażeń wywołanych pałeczkami Salmonella, który wyniósł ponad $18 \% \mathrm{w}$ porównaniu do roku poprzedniego. Liczba ta była większa od mediany $z$ lat 2010-2014 o 8,6\%. W porównaniu do roku 2015 zarejestrowano także wzrost liczby zachorowań na listeriozę, która przewyższyła także medianę z lat 2010-2014.

Table I. Foodborne infections and intoxications registered in Poland in 2010-2016. Number of cases and incidence per 100000 population

Tabela I. Zakażenia i zatrucia pokarmowe zarejestrowane w Polsce w latach 2010-2016. Liczba przypadków i zapadalność na 100000 ludności

\begin{tabular}{|c|c|c|c|c|c|c|}
\hline \multirow{2}{*}{ Foodborne infections and intoxications } & \multicolumn{2}{|c|}{$\begin{array}{c}\text { Median } \\
2010-2014\end{array}$} & \multicolumn{2}{|c|}{2015} & \multicolumn{2}{|c|}{2016} \\
\hline & $\begin{array}{c}\text { number of } \\
\text { cases }\end{array}$ & $\begin{array}{l}\text { incidence } \\
\text { rate }\end{array}$ & $\begin{array}{c}\text { number of } \\
\text { cases }\end{array}$ & $\begin{array}{l}\text { incidence } \\
\text { rate }\end{array}$ & $\begin{array}{c}\text { number of } \\
\text { cases }\end{array}$ & $\begin{array}{l}\text { incidence } \\
\text { rate }\end{array}$ \\
\hline \multicolumn{7}{|l|}{ bacterial } \\
\hline Typhoid/paratyphoid fever & 7 & 0.01 & 9 & 0.01 & 4 & 0.01 \\
\hline Shigellosis & 17 & 0.05 & 18 & 0.05 & 15 & 0.04 \\
\hline Salmonellosis & 9218 & 23.99 & 8420 & 21.90 & 10016 & 26.07 \\
\hline Staphylococcus aureus & 68 & 0.18 & 98 & 0.25 & 38 & 0.10 \\
\hline Clostridium botulinum & 28 & 0.08 & 30 & 0.08 & 26 & 0.07 \\
\hline Clostridium perfringens & 2 & 0.01 & 1 & 0.00 & 2 & 0.01 \\
\hline Other bacterial - specified & 61 & 0.16 & 109 & 0.28 & 13 & 0.03 \\
\hline Listeriosis & 84 & 0.22 & 69 & 0.18 & 99 & 0.26 \\
\hline Leptospirosis & 4 & 0.06 & 4 & 0.10 & 4 & 0.01 \\
\hline Other bacterial - unspecified & 1078 & 2.80 & 1200 & 3.10 & 956 & 2.49 \\
\hline \multicolumn{7}{|l|}{ viral } \\
\hline Viral intestinal infections & 50280 & 130.78 & 55729 & 144.90 & 44830 & 116.66 \\
\hline children under 2 yeras old & 19829 & 1567.27 & 22910 & 3122.60 & 16748 & 11.93 \\
\hline Hepatitis A. & 42 & 0.11 & 49 & 0.13 & 35 & 0.09 \\
\hline \multicolumn{7}{|l|}{ parasitical } \\
\hline Trichinellosis & 16 & 0.36 & 27 & 0.70 & 4 & 0.01 \\
\hline Echinococcosis & 55 & 0.14 & 47 & 0.12 & 63 & 0.16 \\
\hline \multicolumn{7}{|l|}{ other } \\
\hline Acute diarrhoea in children under 2 years & 17728 & 2410.34 & 18781 & 2559.80 & 16675 & 2260.87 \\
\hline mushroom poisonings & 26 & 0.07 & 7 & 0.02 & 45 & 0.12 \\
\hline Berries or other parts of plants poisonings & 3 & 0.01 & 3 & 0.01 & - & - \\
\hline Pesticide poisonings & 16 & 0.04 & 14 & 0.04 & 17 & 0.04 \\
\hline
\end{tabular}

Data sources: Infectious diseases and poisonings in Poland. NIZP-PZH, MZiOS / GIS. Warsaw, Annual Reports: 2010-2016

Źródło: Zakażenia i zatrucia w Polsce. NIZP-PZH / GIS. Warszawa, raporty roczne 2010-2016

In 2016 incidence of foodborne infections and intoxications of bacterial etiology in rural areas was slightly higher than in cities (27.6 and 28.4/100 000 correspondingly). As in previous year incidence most of the cases were among children in the age group 0-4
W 2016 r., w grupie bakteryjnych zatruć pokarmowych (spowodowanych przez odzwierzęce typy pałeczek Salmonella - A02.0, gronkowce - A05.0, Clostridium botulinum - A05.1, C. perfringens - A05.2, a także inne określone bakterie, w tym Vibrio parahaemolyticus 
and accounted for more than $38.5 \%$ of all registered (Tab. IIIA). Incidence among men was slightly higher than in woman (28.7 and 27.2 per 100000 ) (Tab. IIIB).

The number of cases and incidence of foodborne infections of viral etiology, classified as "viral, and other intestinal infections" was lower by $19.5 \%$ than in the previous year and also lower by $10.8 \%$ than the median of incidence per 100000 for the years 2010-2014 (Table I). Regarding infections of parasitic etiology a decrease in the number of trichinellosis cases was recorded- 4 in total, which is also less than the median for 2010-2014. An increase in echinococcosis cases was observed- in total 63 which is more than the median for the years 2010-2014).

In 2016 an increase in mushrooms poisonings (comparing to previous years) was recorded - 45 intoxications, with the incidence of 0.02 (Tab. IIB), which is both bigger that then the median of the number of cases and incidence for the years 2010-2014 (Tab. IIB). i Bacillus cereus - A05.3-A05.8, oraz czynniki nieokreślone - A05.9 zarejestrowano 10734 zachorowania (zapadalność 27,9/100 000). W tej grupie chorób wystąpił wzrost zapadalności i liczby chorych zarówno w porównaniu z 2015 r., jak i w stosunku do mediany z lat 2010-2014. Największą zapadalność zarejestrowano w województwach: pomorskim, lubelskim oraz świętokrzyskim, odpowiednio 37,5; 37,4 oraz 35 na 100000 (Tab. II A). W 2016 r. zapadalność na bakteryjne zatrucia i zakażenia pokarmowe na wsi nieznacznie przewyższała zapadalność w mieście (odpowiednio 28,4 i 27,6 na 100 000). Podobnie jak w poprzednim roku i w latach ubiegłych zgłaszane zachorowania najczęściej dotyczyły dzieci w wieku 0-4 lata. Stanowily one ponad 38,5\% ogółu zarejestrowanych przypadków (Tab. III A). Zapadalność wśród mężczyzn była nieznacznie większa niż wśród kobiet, i wyniosła odpowiednio 28,7 i 27,2 na 100000 (Tab. III B).

Table II A. Bacterial foodborne infections and intoxications registered in Poland in 2010-2016. Number of cases and incidence per 100000 population by voivodeships

Tabela II A. Bakteryjne zakażenia i zatrucia pokarmowe zarejestrowane w Polsce w latach 2010-2016. Liczba przypadków i zapadalność na 100000 populacji województwami

\begin{tabular}{|l|c|c|c|c|c|c|}
\hline \multirow{2}{*}{ Voivodeship } & \multicolumn{2}{|c|}{\begin{tabular}{c}
2 \\
\multicolumn{2}{c|}{2015}
\end{tabular}} & \multicolumn{2}{c|}{2016} \\
\cline { 2 - 7 } & $\begin{array}{c}\text { Median } \\
\text { number of } \\
\text { cases }\end{array}$ & Incidence rate & $\begin{array}{c}\text { number of } \\
\text { cases }\end{array}$ & Incidence rate & $\begin{array}{c}\text { number of } \\
\text { cases }\end{array}$ & Incidence rate \\
\hline Poland & 10296 & 26.75 & 9858 & 25.6 & 10734 & 27.9 \\
\hline Dolnośląskie & 573.5 & 19.75 & 605 & 20.8 & 542 & 18.7 \\
\hline Kujawsko-pomorskie & 487.5 & 23.35 & 472 & 22.6 & 503 & 24.1 \\
\hline Lubelskie & 667 & 31.2 & 536 & 25 & 798 & 37.4 \\
\hline Lubuskie & 204 & 20 & 243 & 23.8 & 165 & 16.2 \\
\hline Lódzkie & 753 & 30.2 & 728 & 29.1 & 778 & 31.3 \\
\hline Małopolskie & 1020.5 & 30.25 & 1009 & 29.9 & 1032 & 30.6 \\
\hline Mazowieckie & 1419 & 26.5 & 1503 & 28.1 & 1335 & 24.9 \\
\hline Opolskie & 225 & 22.55 & 198 & 19.8 & 252 & 25.3 \\
\hline Podkarpackie & 676.5 & 31.8 & 628 & 29.5 & 725 & 34.1 \\
\hline Podlaskie & 328.5 & 27.65 & 282 & 23.7 & 375 & 31.6 \\
\hline Pomorskie & 727.5 & 31.55 & 589 & 25.6 & 866 & 37.5 \\
\hline Śląskie & 1304.5 & 28.55 & 1291 & 28.2 & 1318 & 28.9 \\
\hline Świętokrzyskie & 393.5 & 31.3 & 348 & 27.6 & 439 & 35 \\
\hline Warmińsko-mazurskie & 363 & 25 & 358 & 24.4 & 368 & 25.6 \\
\hline Wielkopolskie & 836.5 & 24.05 & 778 & 22.4 & 895 & 25.7 \\
\hline Zachodniopomorskie & 316.5 & 18.5 & 290 & 16.9 & 343 & 20.1 \\
\hline
\end{tabular}

Data sources: Infectious diseases and poisonings in Poland. NIZP-PZH, MZiOS / GIS. Warsaw, Annual Reports:2010-2016

Źródło: Zakażenia i zatruci a w Polsce. NIZP-PZH / GIS. Warszawa, raporty roczne 2010-2016

\section{Foodborne infections and intoxications in outbreaks}

In 2016 a total number of 680 outbreaks of foodborne diseases were reported, with 22908 exposed persons, 7186 ill persons, including 2750 (over 38\% of all cases in outbreaks) ill children up to 14 years of age. Hospitalization was required for 1603 persons $(22.3 \%$ of all cases in outbreaks). The number of exposed has
Liczba przypadków i zapadalność na zakażenia pokarmowe o etiologii wirusowej, klasyfikowanych jako „wirusowe i inne zakażenia jelitowe” były niższe o $19,5 \%$ niż liczba przypadków w poprzedzającym roku oraz niższa o $10,8 \% \mathrm{w}$ stosunku do mediany zapadalności za lata 2010-2014 (Tab. I).

W odniesieniu do zarażeń o etiologii pasożytniczej odnotowano spadek liczby przypadków włośnicy w sto- 
slightly increased comparing to the previous year and was higher than the median of exposed persons for the years $2010-2014$ by $24 \%$. sunku do 2015 r.- zarejestrowano jedynie 4 zachorowania. Jest to również liczba znacznie mniejsza niż mediana zachorowań na włośnicę z lat 2010-2014. W roku 2016 zarejestrowano 63 przypadki bąblowicy. Było to więcej niż w roku 2015 oraz więcej niż mediana z lat 2010-2014.

Table III. Bacterial foodborne infections and intoxications registered in Poland in 2016. Number of cases, percentage and incidence by age, gender and residence (urban/rural)

Tabela III. Bakteryjne zakażenia i zatrucia pokarmowe zarejestrowane w Polsce w 2016 r. Liczba przypadków, odsetek i zapadalność według wieku, płci i zamieszkania (wieś/miasto)

\begin{tabular}{|l}
\hline A. urban and rural areas \\
\hline A. tereny wiejskie/miejskie \\
\hline
\end{tabular}

Age

group

$0-4$

\begin{tabular}{|l|l}
\hline & \\
\hline
\end{tabular}

1

\begin{tabular}{|l|}
\hline 2 \\
\hline 3
\end{tabular}

4

$5-9$

number of cases

$10-19$

2469

$\% \quad \begin{gathered}\text { incidence } \\ \text { rate }\end{gathered}$

\begin{tabular}{|c|}
\hline $\begin{array}{c}\text { number } \\
\text { of cases }\end{array}$ \\
1668 \\
\hline
\end{tabular}

Rural area

38.6

224.9

172.1

9.2

\begin{tabular}{l|l}
5.8 & 172.1 \\
9.2 & 270.1
\end{tabular}

\begin{tabular}{|l|}
1668 \\
\hline 272 \\
392
\end{tabular}

\begin{tabular}{l|l|l}
8.1 & 239.9 & 345 \\
\hline 8.0 & 233.1 & 367 \\
\hline
\end{tabular}

\begin{tabular}{l|l}
520 & 8.1 \\
513 & 8.0
\end{tabular}

\begin{tabular}{l|l}
233.1 & 367 \\
\hline 209.4 & 292
\end{tabular}

1297

7.4
20.3

110.0

917

\begin{tabular}{l|l}
32.6 & 459
\end{tabular}

\begin{tabular}{l|l}
26.8 & 32.6 \\
\hline 13.1 & 17.0
\end{tabular}

\begin{tabular}{l|l}
\hline $30-39$ & 351
\end{tabular}

9.9

8.9

219

8.1

212

7.8

185

12.9

198
478

27.6

478
4336

100.0

(27.6

\begin{tabular}{c|c}
11.0 \\
478 \\
\hline
\end{tabular}

\section{ea}

\begin{tabular}{|c|c|}
\hline & \\
\hline & incidence \\
\hline
\end{tabular}

Total

6.3
9.0

212.6

181.3

254.4

\begin{tabular}{|l|l|l|}
\hline 8.0 & 221.9 & 865 \\
\hline
\end{tabular}

\begin{tabular}{l|l}
8.0 & 221.9 \\
\hline 8.5 & 230.3 \\
\hline 6.7 & 176.4
\end{tabular}

\begin{tabular}{l|r|}
230.3 & 880 \\
\hline 176.4 & 768
\end{tabular}

\begin{tabular}{|c|c|}
\hline 6.7 & 176.4 \\
\hline 21.1 & 102.6 \\
\hline
\end{tabular}

\begin{tabular}{l|l|l}
\hline 880 & 8.2 & 231.9 \\
\hline 768 & 7.2 & 195.5
\end{tabular}

\begin{tabular}{c|c|c|c|c}
\hline 1.1 & 102.6 & 2214 & 20.6 & 106.8 \\
\hline 10.6 & 27.0 & 1114 & 10.4 & 30.0
\end{tabular}

\begin{tabular}{c|c|c|c|c}
\hline 10.6 & 27.0 & 1114 & 10.4 & 30.0 \\
\hline 5.1 & 9.7 & 555 & 5.2 & 10.9 \\
\hline 4.9 & 8.8 & 563 & 5.2 & 8.9
\end{tabular}

4.9

\begin{tabular}{|l|l|l|}
\hline 4.9 & 8.8 & 563 \\
\hline 4.3 & 8.8 & 430
\end{tabular}

4.3

\begin{tabular}{l|l}
4.3 & 8.8
\end{tabular}

\begin{tabular}{l|l|}
8.8 & 430 \\
\hline 9.7 & 488
\end{tabular}

5.2

\begin{tabular}{l|l}
5.2 & 8.9 \\
4.0 & 8.4
\end{tabular}

9.7
15.4

488

\begin{tabular}{c|c}
28.4 & 1233 \\
\hline
\end{tabular}

4.5
11.5
100.0

8.4

\begin{tabular}{l|l} 
Total & 6398 \\
\hline B. men and women
\end{tabular}

B. mężczyźni/kobiety

\begin{tabular}{|l|c|c|c|c|c|c|c|c|c|}
\hline \multirow{2}{*}{$\begin{array}{l}\text { Age } \\
\text { group }\end{array}$} & $\begin{array}{c}\text { number } \\
\text { of cases }\end{array}$ & $\%$ & $\begin{array}{c}\text { Men } \\
\text { incidence } \\
\text { rate }\end{array}$ & $\begin{array}{c}\text { number } \\
\text { of cases }\end{array}$ & $\%$ & $\begin{array}{c}\text { Women } \\
\text { incidence } \\
\text { rate }\end{array}$ & $\begin{array}{c}\text { number } \\
\text { of cases }\end{array}$ & $\begin{array}{c}\text { Total } \\
\text { incidence } \\
\text { rate }\end{array}$ \\
\hline $0-4$ & 2152 & 40.3 & 222.5 & 1985 & 36.8 & 217.0 & 4137 & 38.3 & 219.8 \\
\hline 0 & 327 & 6.1 & 174.4 & 315 & 5.8 & 177.5 & 642 & 5.9 & 175.9 \\
\hline 1 & 511 & 9.6 & 266.9 & 471 & 8.7 & 260.1 & 982 & 9.1 & 263.6 \\
\hline 2 & 450 & 8.4 & 235.2 & 415 & 7.7 & 229.3 & 865 & 8.0 & 232.4 \\
\hline 3 & 443 & 8.3 & 227.1 & 437 & 8.1 & 237.0 & 880 & 8.1 & 231.9 \\
\hline 4 & 421 & 7.9 & 208.3 & 347 & 6.4 & 181.9 & 768 & 7.1 & 195.5 \\
\hline $5-9$ & 1135 & 21.2 & 106.8 & 1079 & 20.0 & 106.9 & 2214 & 20.5 & 106.8 \\
\hline $10-19$ & 560 & 10.5 & 29.5 & 554 & 28.6 & 29.5 & 992 & 5.1 & 30.0 \\
\hline $20-29$ & 275 & 5.1 & 10.7 & 280 & 5.2 & 10.7 & 760 & 2.6 & 10.9 \\
\hline $30-39$ & 291 & 5.4 & 9.0 & 272 & 5.0 & 9.0 & 565 & 2.5 & 8.9 \\
\hline $40-49$ & 194 & 3.6 & 7.5 & 236 & 4.4 & 7.5 & 380 & 2.2 & 8.4 \\
\hline $50-59$ & 207 & 3.9 & 8.1 & 281 & 5.2 & 8.1 & 590 & 2.6 & 9.4 \\
\hline 60 and $>$ & 531 & 9.9 & 15.0 & 702 & 13.0 & 15.0 & 1161 & 6.5 & 13.8 \\
\hline total & 5345 & 100.0 & 28.7 & 5389 & 100.0 & 27.2 & 10799 & 100.0 & 27.9 \\
\hline
\end{tabular}

Data sources: Infectious diseases and poisonings in Poland. NIZP-PZH, MZiOS / GIS. Warsaw, Annual Report 2016
Źródło: Zakażenia i zatrucia w Polsce. NIZP-PZH / GIS. Warszawa, raport roczny 2016

\section{Etiology of outbreaks}

Most of the outbreaks were caused by zoonotic Salmonella serotypes $(37.6 \%$ of the outbreaks and $28.4 \%$ of the cases). Salmonella Enteritidis was
W 2016 r. zarejestrowano 45 (zapadalność 0,02/ 100 000) zatruć toksynami grzybów. Są to liczby większe niż zgłoszone w 2015 r. i od mediany z lat 20102014 (tab. IIB). 
responsible for $32.5 \%$ of outbreaks and $26.2 \%$ of cases correspondingly, whereas viruses were responsible for $22 \%$ of the outbreaks and $28.5 \%$ of the cases. In $27.3 \%$ of foodborne outbreaks no etiological agent was found (Tab. IV). This is an increase to previous year and the continuation of an increasing trend throughout last couple of years both in the group of small outbreaks (with 1-4 cases) as well as large outbreaks (more than 10 cases) (Fig.1).

\section{Zakażenia i zatrucia pokarmowe w ogniskach}

W 2016 r. zarejestrowano 680 ognisk zatruć/zakażeń chorób przenoszonych drogą pokarmową. Liczna narażonych wyniosła 22908 osób, a zachorowało 7 186, w tym 2750 dzieci do 14 lat (ponad 38\% ogółu zachorowań w ogniskach). Hospitalizacji wymagały 1603 osoby (co stanowiło 22,3\% ogółu zachorowań w ogniskach). Liczba osób narażonych w ogniskach, w porównaniu do poprzedniego roku, wzrosła i była wyższa od mediany z lat 2010-2014 o 24\%.

Table IV. Outbreaks of foodborne and waterborne infections and intoxications in Poland in 2015-2016. Number and percentage of outbreaks and cases by etiological agent

Tabela IV. Ogniska zakażeń i zatruć pokarmowych w Polsce w latach 2015-2016. Liczba przypadków i odsetek według czynnika etiologicznego

\begin{tabular}{|l|c|c|c|c|c|c|c|c|}
\hline \multirow{2}{*}{ Etiological agent } & \multicolumn{4}{|c|}{2015} & \multicolumn{4}{c|}{2016} \\
\cline { 2 - 10 } & \multicolumn{2}{|c|}{ Outbreaks } & \multicolumn{2}{c|}{ Cases } & \multicolumn{2}{c|}{ Outbreaks } & \multicolumn{2}{c|}{ Cases } \\
\cline { 2 - 10 } & number & $\%$ & number & $\%$ & number & $\%$ & number & $\%$ \\
\hline zoonotic Salmonella types & 195 & 34.8 & 1570 & 22.3 & 256 & 37.6 & 2038 & 28.4 \\
\hline Staphylococcus aureus & 5 & 0.9 & 209 & 3.0 & 1 & 0.1 & 3 & 0.0 \\
\hline Escherichia coli & 3 & 0.5 & 31 & 0.4 & 3 & 0.4 & 62 & 0.9 \\
\hline other bacterial agents & 64 & 11.4 & 374 & 5.3 & 71 & 10.4 & 305 & 4.2 \\
\hline viruses & 135 & 24.1 & 2089 & 29.7 & 153 & 22.5 & 2056 & 28.6 \\
\hline poisonous muschrooms & 0 & 0.0 & 0 & 0.0 & 8 & 1.2 & 22 & 0.3 \\
\hline parasites & 21 & 3.8 & 85 & 1.2 & 2 & 0.3 & 6 & 0.1 \\
\hline unknown & 137 & 24.5 & 2679 & 38.1 & 186 & 27.4 & 2694 & 37.5 \\
\hline total & 560 & 100.0 & 7037 & 100.0 & 680 & 100.0 & 7186 & 100.0 \\
\hline
\end{tabular}

Table V. Outbreaks of foodborne and waterborne infections and intoxications caused by Salmonella in Poland in 2015-2016. Number and percentage of outbreaks and cases by serotype

Tabela V. Ogniska zakażeń i zatruc pokarmowych o etiologii Salmonella w Polsce w latach 2015-2016. Liczba i odsetek ognisk według serotypu

\begin{tabular}{|c|c|c|c|c|c|c|c|c|}
\hline \multirow{3}{*}{ Zoonotic Salmonella types } & \multicolumn{4}{|c|}{2015} & \multicolumn{4}{|c|}{2016} \\
\hline & \multicolumn{2}{|c|}{ Outbreaks } & \multicolumn{2}{|c|}{ Cases } & \multicolumn{2}{|c|}{ Outbreaks } & \multicolumn{2}{|c|}{ Cases } \\
\hline & number & $\%$ & number & $\%$ & number & $\%$ & number & $\%$ \\
\hline$S$. Enteritidis & 157 & 80.5 & 1351 & 86.1 & 221 & 86.3 & 1883 & 92.4 \\
\hline S. Typhimurium & 2 & 1.0 & 9 & 0.6 & 6 & 2.3 & 46 & 2.3 \\
\hline S. Kentucky & - & - & - & - & - & - & - & - \\
\hline S. Hadar & 1 & 0.5 & 4 & 2.1 & - & - & - & - \\
\hline$S$. Infantis & 1 & 0.5 & 23 & 1.5 & 1 & 0.4 & 20 & 1.0 \\
\hline S. Virchow & - & - & - & - & 1 & 0.4 & 4 & 0.2 \\
\hline S. Enterica & 3 & 1.5 & 22 & 1.4 & 1 & 0.4 & 4 & 0.2 \\
\hline S. spp & 19 & 9.7 & 116 & 7.4 & 14 & 5.5 & 50 & 2.5 \\
\hline$S$. group B & - & - & - & - & 1 & 0.4 & 4 & 0.2 \\
\hline$S$. group C & 1 & 0.5 & 2 & 0.1 & - & - & - & - \\
\hline$S$. group D & 11 & 5.6 & 43 & 2.7 & 11 & 4.3 & 27 & 1.3 \\
\hline Salmonella - total & 195 & 100.0 & 1570 & 100.0 & 256 & 100.0 & 2038 & 100.0 \\
\hline
\end{tabular}

Among outbreaks of viral etiology noroviruses were responsible for $49.7 \%$ of those outbreaks and $81.5 \%$ of cases and rotaviruses for $48.4 \%$ of outbreaks and $18.2 \%$ of cases.

\section{Czynniki etiologiczne zachorowań w ogniskach}

Najwięcej zidentyfikowanych ognisk było wywołanych przez pałeczki z rodzaju Salmonella (37,6\% ognisk i $28,4 \%$ zachorowań). S. enteritidis była przyczyną $32,5 \%$ 
Salmonella Enteritidis was an etiological agent in $86.3 \%$ of outbreaks causing $92.4 \%$ of cases in the group of zoonotic Salmonella foodborne outbreaks (Tab. V). Comparing to the previous year an increase in percentage of outbreaks of Salmonella etiology in total number of outbreaks and $S$. Enteritidis specifically in the group of outbreaks caused by zoonotic Salmonella outbreaks was recorded. Generally 1883 persons got ill (an increase by $39.4 \%$ comparing to the previous year) in outbreaks caused by $S$. Enteritidis in 2016. Majority of those outbreaks were small outbreaks (where 4 and less persons got sick) and they accounted for over $59 \%$ of all $S$. Enteritidis outbreaks. Household was a place of origin in $74 \%$ of those outbreaks. In 2016 a multistate $S$. Enteritidis outbreak took place, in investigation of which eggs originating from Poland were found as a vehicle (4). ognisk i 26,2\% zachorowań, natomiast czynniki wirusowe wywołały $22 \%$ ognisk i $28,5 \%$ zachorowań. W 27,3\% ognisk nie ustalono czynnika etiologicznego (Tab. IV), co stanowi wzrost w porównaniu do poprzedniego roku oraz kontynuację trendu wzrostowego utrzymującego się od kilku lat. Wzrost liczby i odsetka ognisk o nieustalonej etiologii obserwowano w ogniskach do 4 osób chorych oraz w ogniskach z liczba chorych powyżej 10 (Ryc. 1).

Wśród ognisk o etiologii wirusowej norowirusy były przyczyną 49,7\% ognisk i 81,5\% zachorowań $\mathrm{w}$ ogniskach, natomiast rotawirusy - odpowiednio $48,4 \%$ ognisk oraz $18,2 \%$ zachorowań.

Serotyp Salmonella Enteritidis był czynnikiem etiologicznym $86,3 \%$ ognisk i 92,4\% zachorowań spowodowanych przez odzwierzęce typy pałeczek Salmonella (Tab. V).

Table VI. Outbreaks of foodborne infections and intoxications with infectious and unknown etiological agent in Poland in 2016. Number of outbreaks and cases by etiological agent and setting

Tabela VI. Ogniska zakażeń i zatruć pokarmowych o zakaźnej i nieznanej etiologii w Polsce w 2016 r. Liczba ognisk i przypadków według czynnika etiologicznego i miejsca wystąpienia ogniska

\begin{tabular}{|c|c|c|c|c|c|c|c|c|}
\hline \multirow{2}{*}{\multicolumn{2}{|c|}{ Setting }} & \multicolumn{5}{|c|}{ Etiological agent } & \multirow{3}{*}{\begin{tabular}{|l|} 
total \\
323 \\
\end{tabular}} & \multirow{3}{*}{$\begin{array}{c}\text { total } \\
\%\end{array}$} \\
\hline & & \multirow{2}{*}{$\begin{array}{c}\text { Salmonella } \\
196\end{array}$} & \multirow{2}{*}{$\begin{array}{c}\begin{array}{c}\text { other } \\
\text { bacterial } \\
\text { agents }\end{array} \\
11\end{array}$} & \multirow{2}{*}{$\begin{array}{c}\text { viruses } \\
59 \\
\end{array}$} & \multirow{2}{*}{$\begin{array}{c}\text { parasites } \\
2\end{array}$} & \multirow{2}{*}{$\begin{array}{c}\text { unknown } \\
\text { agent }\end{array}$} & & \\
\hline household, domestic & outbreaks & & & & & & & \\
\hline kitchen & cases & 715 & 31 & 175 & 6 & 193 & 1120 & 15.6 \\
\hline \multirow{2}{*}{$\begin{array}{l}\text { restaurant, bar, hotel, } \\
\text { catering }\end{array}$} & outbreaks & 25 & - & 33 & - & 55 & 113 & 16.8 \\
\hline & cases & 331 & - & 670 & - & 836 & 1837 & 25.6 \\
\hline \multirow{2}{*}{ nursery, kindergarten } & outbreaks & 20 & - & 3 & - & 8 & 31 & 4.6 \\
\hline & cases & 475 & - & 34 & - & 99 & 608 & 8.5 \\
\hline \multirow{2}{*}{ school } & outbreaks & 5 & - & 6 & - & 7 & 18 & 2.7 \\
\hline & cases & 423 & - & 237 & - & 179 & 839 & 11.7 \\
\hline \multirow{2}{*}{ camp or school trip } & outbreaks & 1 & - & 1 & - & 2 & 4 & 0.6 \\
\hline & cases & 2 & - & 14 & - & 28 & 44 & 0.6 \\
\hline \multirow{2}{*}{$\begin{array}{l}\text { children's home, } \\
\text { boarding schools }\end{array}$} & outbreaks & 1 & 1 & 5 & - & 6 & 13 & 1.9 \\
\hline & cases & 21 & 49 & 258 & - & 248 & 576 & 8.0 \\
\hline \multirow{2}{*}{ social care } & outbreaks & - & - & 1 & - & 6 & 7 & 1.0 \\
\hline & cases & - & - & 42 & - & 87 & 129 & 1.8 \\
\hline \multirow{2}{*}{ hospital } & outbreaks & 2 & 60 & 41 & - & 32 & 135 & 20.1 \\
\hline & cases & 22 & 278 & 418 & - & 622 & 1340 & 18.7 \\
\hline \multirow{2}{*}{$\begin{array}{l}\text { sanatorium, rehabilitation } \\
\text { center }\end{array}$} & outbreaks & - & 2 & 3 & - & 7 & 12 & 1.8 \\
\hline & cases & - & 9 & 166 & - & 196 & 371 & 5.2 \\
\hline \multirow{2}{*}{ other setting } & outbreaks & 6 & 1 & 1 & - & 8 & 16 & 2.4 \\
\hline & cases & 49 & 3 & 42 & - & 206 & 300 & 4.2 \\
\hline \multirow{2}{*}{ total } & outbreaks & 256 & 75 & 153 & 2 & 186 & 672 & \\
\hline & cases & 2038 & 370 & 2056 & 6 & 2694 & 7164 & \\
\hline \multirow{2}{*}{ total $\%$} & outbreaks & 38.1 & 11.2 & 22.8 & 0.3 & 27.7 & & 100.0 \\
\hline & cases & 28.4 & 5.2 & 28.7 & 0.1 & 37.6 & & 100.0 \\
\hline
\end{tabular}

In 2016 there were 2 outbreaks of parasitic etiology reported $(0.3 \%$ of all outbreaks and $0.08 \%$ of cases in all outbreaks), one of which was caused by trichinellosis and the other by giardiasis.

There were 6 outbreaks reported in 2016 with the case number exceeding 100 . Two of them were caused by $S$. Enteritidis, other two by Norovirus and in last two no etiological agent was found.
W porównaniu do poprzednich lat nastąpił wzrost zarówno w odsetku ognisk wywołanych przez pałeczki Salmonella w ogólnej liczbie ognisk jak i udziału serotypu $S$. Enteritids w liczbie ognisk i zachorowań w ogniskach wywołanych odzwierzęcymi typami pałeczek Salmonella. Pałeczki $S$. enteritidis były przyczyną zachorowania 1883 osób w ogniskach, co stanowi wzrost o $39,4 \%$ w porównaniu do poprzedniego roku. 


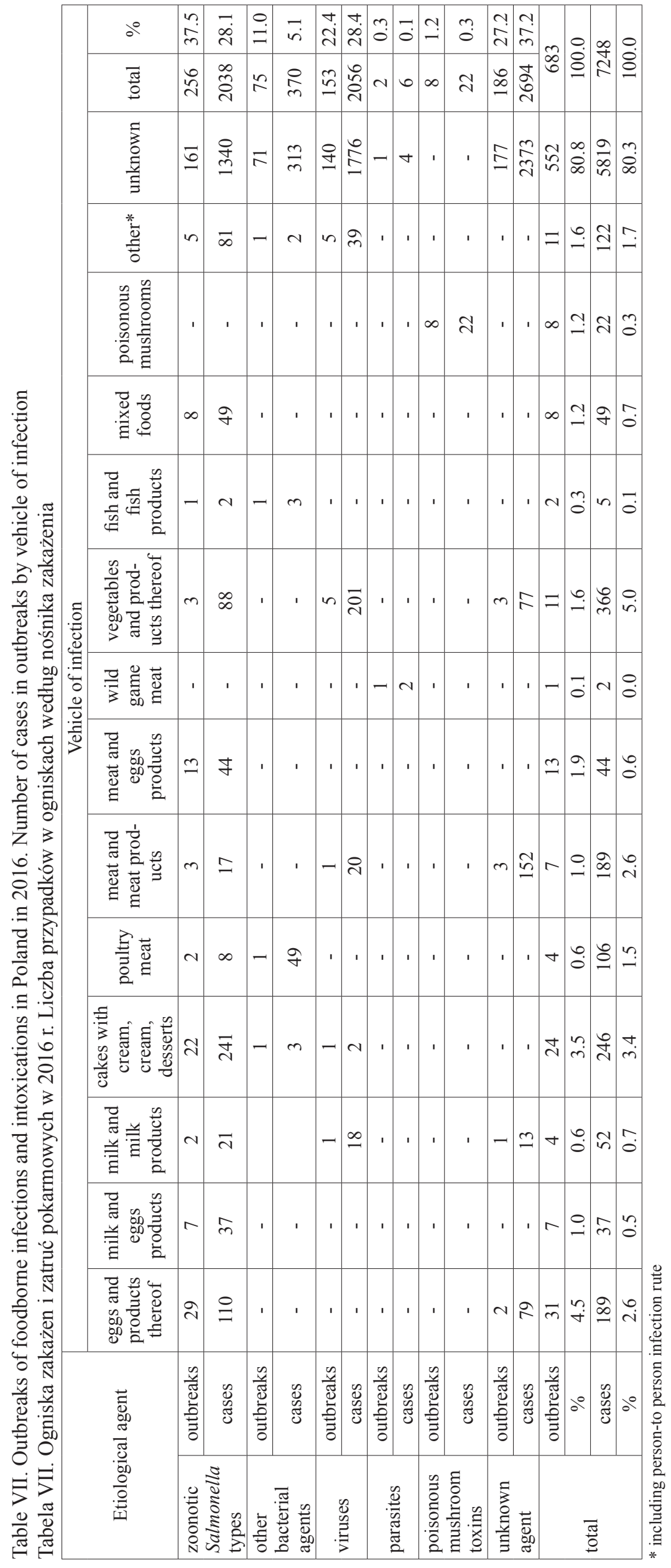




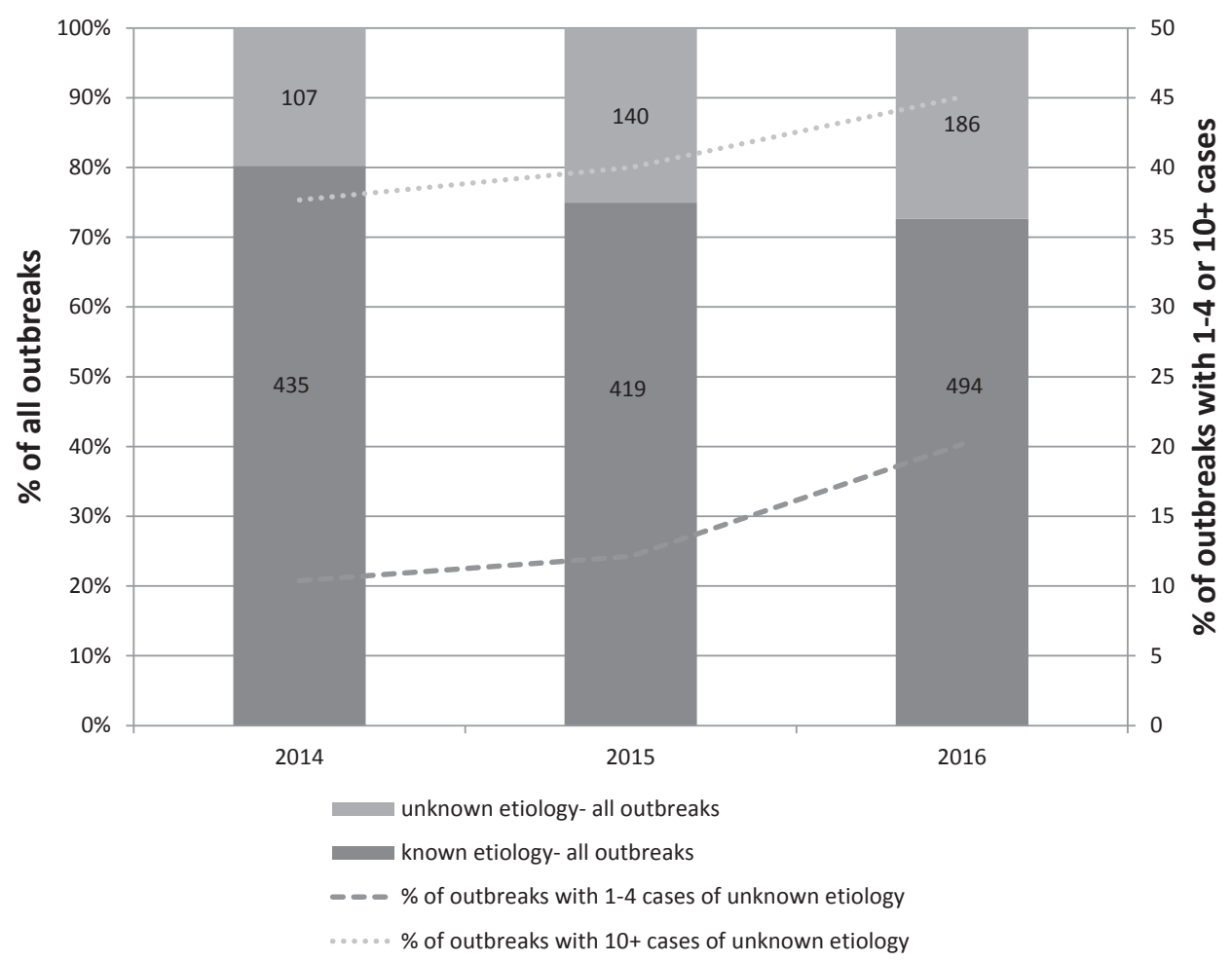

Fig. 1. Foodborne outbreaks 2014-2016. Percentage of outbreaks with known and unknown etiology 2014-2016, including unknown etiology with 1-4 and more than 10 cases

Ryc. 1. Ogniska pokarmowe 2014-2016. Odsetek ognisk z nieokreślonym i określonym czynnikiem etiologicznym 20142016, w tym o niustalonej etiologii z 1-4 i wiecej niż 10 chorymi

\section{Places of occurrence of outbreaks}

Just as in previous years, in 2016 the most frequent place of occurrence of outbreaks was private household (323 outbreaks, 1120 cases). Among those over $52 \%$ were of $S$. Enteritidis etiology and in $17 \%$ no etiological agent was found. Majority of those outbreaks (over $81 \%$ ) were small outbreaks (4 and less cases per outbreak).

In 2016 there were 135 hospital outbreaks with 1340 cases. The most frequent etiological agent in hospital outbreaks was Clostridium difficile (60 outbreaks and 270 cases) followed by rotavirus (24 outbreaks and 227 cases).

\section{Vehicles identified in outbreaks}

The most frequent vehicle of infection in 2016 were (same as in previous year) eggs and egg products (4.6\% of outbreaks and $2.6 \%$ of cases), followed by cakes and desserts (3.5\% of outbreaks, $3.4 \%$ of cases). In $550(80.9 \%)$ in which 5806 persons fell ill $(80.8 \%)$ no vehicle of infection was found, which is an increase comparing to the previous year (Tab. VII) (3). In 2016 there was a decrease in the percentage of outbreaks with 10 and more case, which occurred during organized venues, and from which at least one food sample was taken for testing. Yearly this number is was around $45 \%$ and in 2016 it was $40.2 \%$.
W większości były to małe ogniska rodzinne, w których chorowało 4 lub mniej osób. Stanowiły one ponad $59 \%$ ognisk o etiologii $S$. enteritidis, a ich miejscem wystąpienia było mieszkanie/dom (74\%). W 2016 r. miało miejsce międzynarodowe ognisko o etiologii Salmonella enteritidis, w którym wykazano związek między zachorowaniami ludzi a konsumpcją jaj pochodzących z Polski (4).

W 2016 roku odnotowano 2 ogniska wywołane przez czynniki pasożytnicze (odpowiednio $0,3 \%$ ognisk i $0,08 \%$ ogółu zachorowań w ogniskach). Jedno z nich dotyczyło zachorowań na włośnicę, a drugie na giardiozę.

W 2016 r. zarejestrowano 6 ognisk, w których zachorowało więcej niż 100 osób. W dwóch z nich czynnikiem etiologicznym były pałeczki Salmonella enteritidis, w kolejnych dwóch norowirusy, a w dwóch pozostałych nie ustalono czynnika etiologicznego.

\section{Miejsca występowania ognisk}

Tak jak w poprzednich latach, najczęstszym miejscem, w którym występowały ogniska było gospodarstwo domowe - 323 ogniska, 1120 zachorowań (Tab. VI). Wśród tych ognisk ponad $52 \%$ było o etiologii $S$. enteritidis, a w $17 \%$ nie ustalono czynnika etiologicznego. W ponad $81 \%$ były to ogniska, w których chorowało do 4 osób. 


\section{Clinical presentations of cases in outbreaks}

The clinical presentation of cases in 2016, in reference to the specific etiological agent or a group of etiological agents, was as follows:

- in diseases caused by Salmonella diarrhea was the most prevalent and occurred in $87.5 \%$ of patients, than abdominal pain (cramps) $(63.9 \%)$ and fever (59.4\%);

- in diseases caused by viruses the most frequent symptoms were vomiting (in $66.8 \%$ of cases), diarrhea (in $61 \%$ of cases), and abdominal pain (cramps) (47.4\% of cases);

- among the cases caused by other bacterial etiology diarrhea occurred in $79.5 \%$ of patients, and abdominal pain in $27.6 \%$;

- among the cases caused by unknown etiology dominated diarrhea $(67.4 \%)$, vomiting $(53.9 \%)$ and abdominal pain (44.9\%), which might suggest that majority of those outbreaks were of viral etiology (as well as the fact that fever was present only in $17.7 \%$ of cases in those outbreaks). It also consistent with clinical presentation of cases in unknown etiology outbreaks in previous years (Fig. 2).
W 2016 r. odnotowano 135 ognisk, które miały miejsce w szpitalach. Łącznie zachorowało w nich 1340 osób. Najczęstszym czynnikiem etiologicznym tych ognisk były zakażenia o etiologii Clostridium difficile - 60 ognisk, 278 chorych. Rotawirusy były czynnikiem etiologicznym 24 ognisk, które wystąpiły w szpitalach i zachorowało w nich łącznie 227 osób.

\section{Nośniki zakażeń w ogniskach}

Najczęstszym nośnikiem zakażenia w 2016 roku były, podobnie jak rok wcześniej, potrawy zaliczane do jaj i produktów z jaj (4,6\% ognisk, 2,6\% zachorowań), a następnie ciast i deserów (łącznie 3,5\% ognisk, 3,4\% zachorowań). W 550 (80,9\%) ogniskach, w których zachorowało 5806 osób $(80,8 \%)$ nie ustalono nośnika zakażenia, co stanowi wzrost w porównaniu do poprzedniego roku (Tab. VII) (3). W 2016 roku zmniejszył się odsetek ognisk z liczbą chorych powyżej 10 osób, które wystąpiły w związku z imprezą zorganizowaną, a w których pobrano co najmniej jedną próbkę żywności do badań mikrobiologicznych. Wspomniany odsetek w tego rodzaju ogniskach rokrocznie (20142015) sięgał około 45\%, natomiast w 2016 roku wyniósł $40,2 \%$.

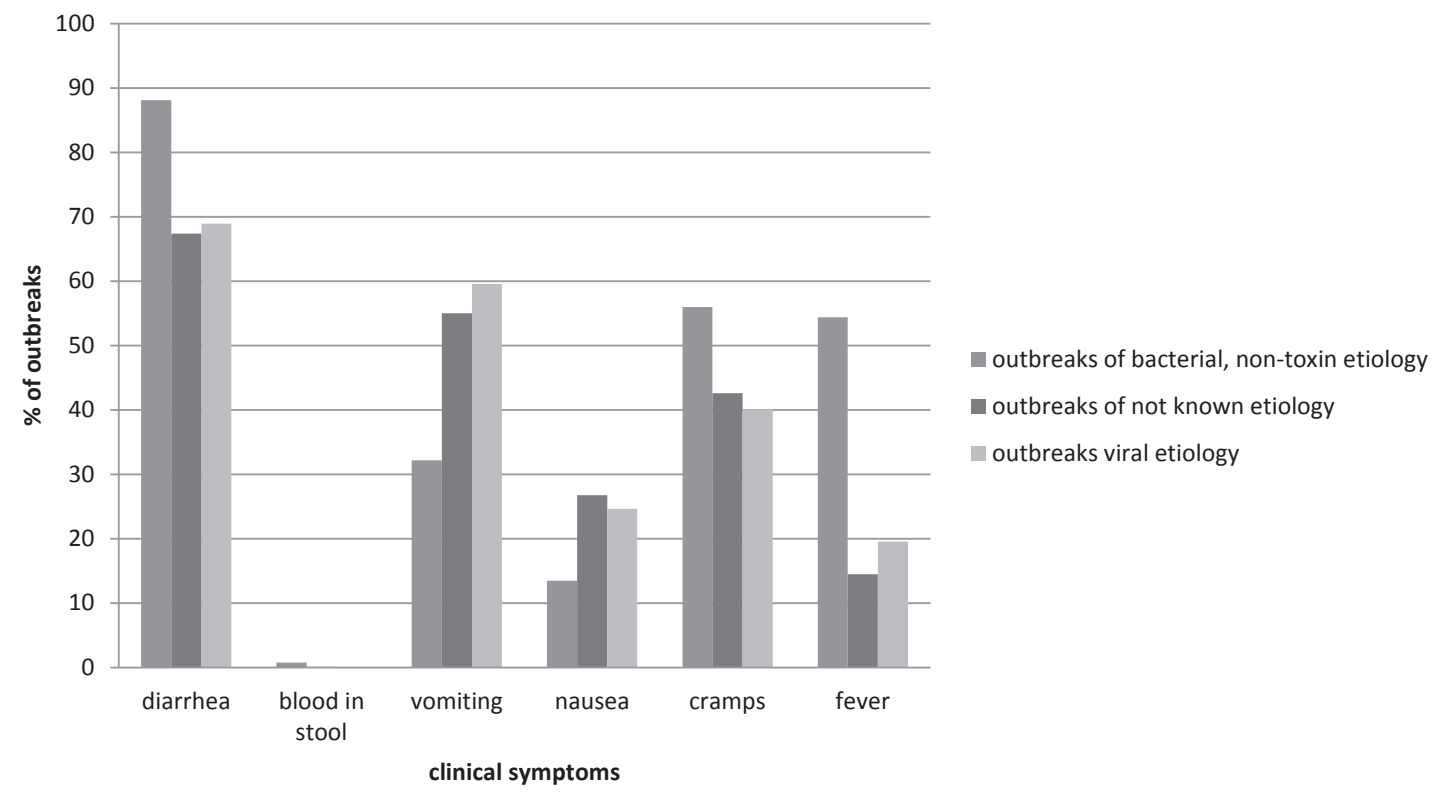

Fig. 1. Foodborne outbreaks 2014-2016. Percentage of outbreaks with known and unknown etiology 2014-2016, including unknown etiology with 1-4 and more than 10 cases

Ryc. 1. Ogniska pokarmowe 2014-2016. Odsetek ognisk z nieokreślonym i określonym czynnikiem etiologicznym 20142016, w tym o niustalonej etiologii z 1-4 i wiecej niż 10 chorymi

As in previous years outbreaks have been reported to the European Union database operated by EFSA, in accordance with the criteria set by this organization. Only outbreaks with data suggesting an involvement of food products or where such relation cannot be disproven are reported to this database. In 2016 a total number of 472 outbreaks was reported (2), among which $126(26.7 \%)$ were classified as strong-evidence

\section{Obraz kliniczny zachorowań w ogniskach}

Obraz kliniczny zachorowań, w roku 2016 w zależności od czynnika etiologicznego przedstawiał się następująco:

- w zachorowaniach spowodowanych przez pałeczki Salmonella dominowały: biegunka, która wystąpiła u $87,5 \%$ chorych, bóle brzucha $(63,9 \%)$ oraz gorączka $(59,4 \%)$ 
outbreaks (with the proven link between the illness and food consumption), which was 59 more than in 2015. In 31 outbreaks (6.6\%) evidences mentioned were laboratory (microbiologically) supported (in food samples or surfaces swabs the same agent was discovered as in samples taken from the cases), in 39 $(8.3 \%)$ of outbreaks the epidemiological proofs were found (link between food consumption and falling ill proven by epidemiological analysis), and in 83 (17.6\%) the link resulted from the descriptive epidemiology).

\section{SUMMARY AND CONCLUSIONS}

1. Increasing numbers of $S$. Enteritidis foodborne outbreaks and cases of S. Enteritidis infection in outbreaks along with the fact that the most frequent vehicle of infection in those outbreaks were eggs and egg products, indicates the need of tightening of surveillance over those products both in primary production and in retail.

2. Increasing yearly percentage of outbreaks of unknown etiology, with cases showing symptoms consistent with viral etiology, indicates the need for performing viral testing more readily and frequently in the course of epidemiological investigations.

3. A large percentage of unknown outbreaks with 10 and more cases, connected to organized venue, with no food sample tested, which also increased in 2016, could indicate the lack of food samples to be tested during epidemiological investigations in these outbreaks. It might justify the need of reinstatement of 48-hour mandatory storage of food samples from organized venues by the organizers or developing other mechanisms increasing their availability for testing, especially when it comes to outbreaks among children and elderly persons.

\section{REFERENCES}

1. Czarkowski MP et al., Infectious diseases and poisonings in Poland - in 2016, Warsaw, NIPHNIH and GIS, Warsaw 2016

2. EFSA, ECDC, The European Union summary report on trends and sources of zoonoses, zoonotic agents ad food-borne outbreaks in 2016, EFSA Journal 2017;15(12):5077

3. Polanski P, Kosyra M, Sadkowska-Todys M, Foodborne infections and intoxications in Poland in 2015, Epidemiological Review 2017;71(4);501511

4. EFSA, ECDC, Multi-country outbreak of S. Enteritidis linked to Polish eggs, Joint Rapid Outbreak Assessment, 12th December 2017 w zachorowaniach spowodowanych przez wirusy dominowały wymioty (u $66,8 \%$ chorych) biegunka (61\%), oraz bóle brzucha $(47,4 \%)$.

- w zachorowaniach spowodowanych innymi czynnikami bakteryjnymi występowały- biegunka (u 79,5\% chorych), bóle brzucha (27,6\%);

- w zachorowaniach w ogniskach o nieustalonej etiologii przeważały biegunka $(67,4 \%)$, wymioty $(53,9 \%)$ oraz bóle brzucha $(44,9 \%)$, co może nasuwać podejrzenie, że większość z tych ognisk miało etiologię wirusową, podobnie jak fakt, że tylko u $17,7 \%$ chorych w ogniskach o nieustalonej etiologii wystąpiła gorączka. Jest to zgodne z obrazem klinicznym ognisk o nieustalonej etiologii z lat wcześniejszych (Ryc. 2).

Dane $\mathrm{z}$ ognisk zostały przekazane $\mathrm{w}$ formie jednostkowych raportów do unijnej bazy prowadzonej przez EFSA (European Food Safety Authority), zgodnie z przyjętymi w niej kryteriami i definicjami. Raportowane do tej bazy są ogniska, których wystąpienie miało związek ze spożywaniem skażonej żywności, lub nie można było tego związku wykluczyć. Ogółem zgłoszono 472 ognisk (2), wśród których było 126 $(26,7 \%)$ zakwalifikowanych jako ogniska $\mathrm{z}$ silnymi dowodami potwierdzającymi związek zachorowań ze spożyciem określonego produktu spożywczego. W 31 ogniskach $(6,6 \%)$ dowody miały charakter mikrobiologiczny (w żywności lub w wymazach sanitarnych wykryto ten sam czynnik etiologiczny co u chorujących w ognisku ludzi), w 39 (8,3\%) były to dowody epidemiologiczne (w badaniach analitycznych wykazano związek wystąpienia zachorowania ze spożyciem określonego produktu spożywczego), a w 83 ogniskach $(17,6 \%)$ związek ten wynikał z opisu epidemiologicznego ogniska.

\section{PODSUMOWANIE I WNIOSKI}

1. Wzrastająca liczba ognisk, jak również zachorowań w ogniskach o etiologii S. enteritidis w połączeniu z faktem, że najczęściej identyfikowanym nośnikiem zakażenia $\mathrm{w}$ tych ogniskach są jaja i produkty z jaj wskazują na konieczność zaostrzenia nadzoru nad tymi produktami, zarówno w obrębie produkcji pierwotnej, jak i obrocie.

2. Wzrastający rokrocznie odsetek ognisk o nieustalonej etiologii, w których objawy u chorych są charakterystyczne dla ognisk o etiologii wirusowej, wskazuje na potrzebę rutynowego wykonywania badań laboratoryjnych we wspomnianych ogniskach w kierunku tych czynników.

3. Duży odsetek ognisk o liczbie chorych powyżej 10 osób, związanych z imprezą zorganizowaną, w których nie pobrano żadnej próbki żywności do badań wynika z braku ich dostępności podczas 
Received: 5.12.2018

Accepted for publication: 10.12.2018

Otrzymano: 5.12.2018 r.

Zaakceptowano do publikacji: $10.12 .2018 \mathrm{r}$.

Address for correspondence:

Adres do korespondencji:

Piotr Polański

Zakład Epidemiologii Chorób Zakaźnych i Nadzoru Narodowy Instytut Zdrowia Publicznego-PZH

ul. Chocimska 24, 00-791 Warszawa

Tel.+48 225421206

e-mail:ppolanski@pzh.gov.pl dochodzenia epidemiologicznego. Wskazuje to na zasadność przywrócenia obowiązku przechowywania próbek żywności przez organizatora imprezy przez okres 48 godzin od jej zakończenia lub wypracowanie innych mechanizmów zapewniających ich dostępność, w szczególności w przypadku ognisk dotyczących małych dzieci lub osób starszych.

\section{REFERENCES}

1. Czarkowski MP i in. Choroby zakaźne i zatrucia w Polsce w 2016 roku, NIZP-PZH, Zakład Epidemiologii, GIS, Departament Zapobiegania oraz Zwalczania Zakażeń i Chorób Zakaźnych u Ludzi, Warszawa 2017

2. EFSA, ECDC, The European Union summary report on trends and sources of zoonoses, zoonotic agents ad food-borne outbreaks in 2016, EFSA Journal 2017;15(12):5077

3. Polański P, Kosyra M, Sadkowska-Todys M, Zatrucia i zakażenia pokarmowe w Polsce w 2015 roku., Przegl Epidemiol 2017;71(4);501-511

4. EFSA, ECDC, Multi-country outbreak of S. Enteritidis linked to Polish eggs, Joint Rapid Outbreak Assessment, 12 ${ }^{\text {th }}$ December 2017 